\title{
Poly herbal extraction for analgesic and anti-inflammatory activity
}

\author{
Chitta Venkateswararao $^{1 *}$, K. Venkataramana ${ }^{2}$, V.V. Rajesham ${ }^{3}$, G.Nagaurjunareddy ${ }^{4}$ \\ ${ }^{I}$ Chitta Venkateswararao A.S.N Pharmacy College,Burripalem Road, Tenali- 522 201, Guntur Dist., A.P. (A.P) India \\ ${ }^{2}$ A.S.N Pharmacy College,Burripalem Road, Tenali \\ ${ }^{3}$ Vijaya College of Pharmacy, Munganoor, Hyathnagar, Hyderabad \\ ${ }^{4}$ K.L.R.College of Pharmacy, Palvoncha \\ *Corresponding author E-mail: chitta_2013@rediffmail.com
}

\begin{abstract}
The analgesic and anti-inflammatory activity of the poly herbal formulation (composed of the extracts from Terminalia chebula, tinospora cordifolia, Phyllanthus emblica, Portulaca oleracea) was evaluated in Acetic Acid Induced Writhing Method, Eddy's Hot Plate Method: (Thermal stimulus), Carrageenan induced hind paw edema. The extract at dose of $200,400 \mathrm{mg} / \mathrm{kg}$ produced significant inhibition of oedema and pain induced by above mentioned methods. The result obtained suggesting that extract possesses significant analgesic and anti-inflammatory activity.
\end{abstract}

Keywords: Analgesic, Anti Inflammatory, Phyllanthus Emblica, Portulaca Oleracea, Terminalia Chebula, Tinospora Cordifolia.

\section{Introduction}

India is much known for its variety of agro-climatic diversity and also for its rich heritage of traditional systems of medicines. The Indian System of Medicine (ISM) comprises of Ayurveda, Siddha, Unani and Tibetan system of medicine along with the other folk medicinal practices and age old home remedies. All these systems have placed India, as the leading nation in using natural medicinal therapeutic field, which is based on the traditional knowledge of the use of medicinal plants. India possesses a rich treasure of biodiversity, which has been used for health care, for the last more than four thousand years. Medicinal plants are those plants that contain substances which could be used for therapeutic purposes or which are precursors for the synthesis of useful drugs (Neetu Sharma et al. 2013) Pain has been defined by International Association for the Study of Pain (IA+SP) as an unpleasant sensory and emotional experience associated with actual or potential tissue damage. Clinically, pain can be labeled "nociceptive" if it is inferred that the pain is due to ongoing activation of the nociceptive system by tissue injury. Although neuroplastic changes (such as those underlying tissue sensitization) are clearly involved, nociceptive pain is presumed to occur as a result of the normal activation of the sensory system by noxious stimuli, a process that in volves transduction, transmission, modulation and perception Materials and methods (Amrita Kumari et al. 2013). Drugs which are used currently for pain management $\&$ inflammatory conditions are either narcotic analgesics or NSAID ${ }^{\text {ee }} \mathrm{S}$ and steroids. All the above said drugs possess adverse \& toxic effects such as addiction, constipation and respiratory depression in case of narcotic analgesics peptic ulcers and kidney problems in NSAID ${ }^{\text {ee }}$. So to avoid adverse effects from these medicines, potent and safe medicine from plant origin has been used since long time. It is essential that efforts should be made to introduce new medicinal plants to develop cheaper drugs. Plants represent still a large untapped source of structurally novel compounds that might serve as a beacon light for the development of novel drugs (Nithyamala I et al. 2013). A poly herbal Ayurvedic formulation composed of 4 plant ingredient was tried for its analgesic and anti-inflammatory activities. Some of its constituents like Terminalia chebula, tinospora cordifolia, Phyllanthus emblica, and Portulaca oleracea claimed to reduce inflammation and pain. The present study is therefore an attempt to assess the PHME (Poly Herbal Methanolic Extraction) for its analgesic and anti-inflammatory activities using various animal models.

\section{Materials and methods:}

\subsection{Plants}

Almost all the plant materials were collected from the forest region of Tamil Nadu and they were identified and authenticated by Dr. Vastavya S. Raju, Department of Botany, Kakatiya University, and Warangal.

The parts proposed for this study were separated from the whole plant and kept for air drying under shadow (i.e. avoiding direct exposure to sunlight) and were subjected for size reduction.

\subsection{Preparation of poly herbal extract}

A wide range of solvents with increasing polarity were chosen. Step.1: In a $250 \mathrm{ml}$ round bottomed flask, weighed quantity of powdered drug were macerated with the respective solvents in the ratio of 1:2 (i.e. $50 \mathrm{gm}$ in $100 \mathrm{ml}$ ) and kept with occasional shaking for a period of $72 \mathrm{hrs}$. After the maceration process, the active ingredients present in the supernatant solvent were collected in Petri dishes and concentrated under reduced pressure. 
Step.2: These extracts were labeled and its chemical constituents were identified, among the different solvent extracts, the extract possessing more number of active compounds were selected and prepared for bulk extraction similar as step 1 .

\subsection{Animal studies}

\subsubsection{Toxicity studies}

Albino rats (200-250gm) of either sex were selected and segregated in to 8 groups of 6 animals each. Single dose of methanolic extract of poly herbal formulation, starting from the minimal dose of $50 \mathrm{mg} / \mathrm{kg}$ up to $3000 \mathrm{mg} / \mathrm{kg}$ administered orally. The drug treated animals were observed carefully for its toxicity signs and mortality. From the maximum dose, $1 / 5^{\text {th }}$ and $1 / 10^{\text {th }}$ of the concentration was considered as therapeutic dose for further study.

\subsubsection{Animals}

Albino rats (175-225gm) of either sex and of approximate same age used in the present studies were procured from Central Animal facility, Vijaya college of Pharmacy, Hyderabad, India. The animal was fed with standard pellet diet and water ad libitum. All the animals were housed in polypropylene cages. The animals were kept under alternate cycle of 12 hours in darkness and light. The animals were acclimatized to the laboratory condition for a one week before starting the experiment. The experiment protocols were approved by Institutional Animal Ethics committee after securitization (IAEC No: P22/VCP/IAEC/2013/3/VVR/AE2). The animal received the drug treatment by oral gavage tube.

\subsection{Methods}

\subsubsection{Acetic acid induced writhing method (Ezeja M I et al 2011)}

This study was carried out using acetic acid induced abdominal writhing reflex pain model. Thirty five mature mice were randomly divided into 4 groups (1-4) of 6 mice per group, fasted for 12 hours and treated as follows, Group 1 (control group) received $10 \mathrm{ml} / \mathrm{kg}$ normal saline, group 2 (standard) received $30 \mathrm{mg} / \mathrm{kg}$ of Diclofenac sodium; groups 3 and 4 received 200 and $400 \mathrm{mg} / \mathrm{kg}$ of PHME respectively using gastric gavage. One hour after drug and extract administration, $0.6 \%$ glacial acetic acid $(10 \mathrm{ml} / \mathrm{kg})$ was administered intraperitoneally (I.P) to all the mice to induce abdominal contortions or writhings. The analgesic effect was assessed in each mouse for 30,60,120 minutes and recorded. The degree of analgesia was calculated using the following formula

Mean of control group-mean of treated group

$$
\text { Mean of control group }
$$

This represents the percentage of inhibition of writhing.

2.4.2. Eddy's hot plate method: (thermal stimulus) (Vijusha M et al. 2013)

In the hot plate method albino mice (18-28) were divided into four groups each consisting of six animals. All the animal selected for the studied were under gone the normal basal reaction time and then separated as different groups like Group I served as a control (received vehicle), Group II served as a standard (received Diclofenac sodium $30 \mathrm{mg} / \mathrm{kg}$ ) while the Group III and IV received the PHME (200 and $400 \mathrm{mg} / \mathrm{kg}$ respectively). All animals were lowered onto the surface of a hot plate $\left(50 \pm 1.00^{\circ} \mathrm{C}\right)$ enclosed with cylindrical glass and the time for the animal to jump or lick the fore limb was noted as the reaction time (RT). Cut off time in the absence of a response was $15 \mathrm{sec}$ to prevent the animals from being burnt. The observations were made before and after administration of respective drugs at $30 \mathrm{~min}, 60 \mathrm{~min}, 120 \mathrm{~min}$, and at the end of $180 \mathrm{~min}$

\subsubsection{Carrageenan induced hind paw edema (Kalpanadevi V et al. 2012)}

Albino rats of either sex weighing 150-200 grams were divided into four groups of six animals each. The dosage of the drugs administered to the different groups was as follows. Group I - Control (normal saline $0.5 \mathrm{ml} / \mathrm{kg}$ ), Group II - Diclofenac sodium (30 $\mathrm{mg} / \mathrm{kg}$, p. o.), Group - III and IV - PHME (200 mg/kg and 400 $\mathrm{mg} / \mathrm{kg}$, p. o.). All the drugs were administered orally. Diclofenac sodium served as the reference standard anti-inflammatory drug. After one hour of the administration of the drugs, $0.1 \mathrm{ml}$ of $1 \%$ W/V carrageenan solution in normal saline was injected into the sub plantar tissue of the left hind paw of the rat and the right hind paw was served as the control. The paw volume of the rats were measured in the digital plethysmograph (Ugo basile, Italy), at the end of $0 \mathrm{~min}$., $60 \mathrm{~min} ., 120 \mathrm{~min}$., $180 \mathrm{~min}$. and $240 \mathrm{~min}$. The percentage increase in paw edema of the treated groups was compared with that of the control and the inhibitory effect of the drugs was studied. The relative potency of the drugs under investigation was calculated based upon the percentage inhibition of the inflammation.

$$
\text { Percentage inhibition }=\frac{\text { Control }\left(\% \text { increase in paw volume in } 3^{\text {rd }} \text { hour }\right)-\text { Test }\left(\% \text { increase in paw volume in } 3^{\text {rd }} \text { hour }\right)}{\text { Control }\left(\% \text { increase in paw volume in } 3^{\text {rd }} \text { hour }\right)}
$$

\begin{tabular}{|c|c|c|c|c|c|c|c|c|}
\hline \multirow{2}{*}{ Groups } & \multirow{2}{*}{ Treatment } & \multirow{2}{*}{ Dose } & \multicolumn{3}{|c|}{ Number of writhing (Mean \pm SEM) } & \multicolumn{3}{|c|}{$\%$ inhibition of writhing } \\
\hline & & & $30 \min$ & $60 \mathrm{~min}$. & $120 \mathrm{~min}$ & $30 \mathrm{~min}$ & $60 \mathrm{~min}$. & $120 \mathrm{~min}$ \\
\hline Group- I & Control & $0.1 \mathrm{ml}$ & $26.66 \pm 3.602$ & $27.66 \pm 4.356$ & $35.83 \pm 4.199$ & & & \\
\hline Group-II & Standard (Diclofenac sodium) & $30 \mathrm{mg} / \mathrm{kg}$ & $13.33 \pm 1.33 * *$ & $8.66 \pm 1.02 * *$ & $3.66 \pm 1.25 * *$ & 62.79 & 75.83 & 89.78 \\
\hline Group- III & PHME & $200 \mathrm{mg} / \mathrm{kg}$ & $16.42 \pm 1.81 * *$ & $12.14 \pm 1.87 * *$ & $.64 * *$ & 54.17 & 66.11 & 76.08 \\
\hline Group-IV & PHME & $400 \mathrm{mg} / \mathrm{kg}$ & $14.5 \pm 0.99 * *$ & $9.83 \pm 0.30 * *$ & $5.83 \pm 1.40 * *$ & 59.53 & 72.56 & 83.72 \\
\hline
\end{tabular}

Table 1: Acetic Acid Induced Writhing Test in Mice:

\section{Results and discussion}

\subsection{Acetic acid induced writhing test in mice}

The PHME with two selected doses i.e. 200 and $400 \mathrm{mg} / \mathrm{kg}$ have exhibited significant increase percentage of inhibition in writhing method in mice at different time intervals. Results were shown in Table No.1 Diclofenac sodium $(30 \mathrm{mg} / \mathrm{kg}$ ) was used as standard and it has significantly increased the percentage inhibition of writhing by $89.7 \%$ at the end of $2 \mathrm{hr}$ which was found to be a time dependent effect. During first $30 \mathrm{~min}$ of the study PHME with medium and high dose the \% of inhibition of writhing were 54.12, and $59.53 \%$.During $1 \mathrm{hr}$ of the study PHME with medium and high dose the \% of inhibition of writhing was 66.11 and $72.56 \%$ respectively which was time dependent effect. During $2 \mathrm{hr}$ of the study PHME with medium and high dose the $\%$ of inhibition of writhing was 76.08 and $83.72 \%$ and the results were tabulated. Values indicate mean \pm SEM (ANNOVA test followed by Dunnet's t- test)

Control $\mathrm{n}=6$ : comparison with control group. 


\subsection{Analgesic activity by eddy's hot plate test in mice}

The PHME with two selected doses i.e. 200 and $400 \mathrm{mg} / \mathrm{kg}$ have exhibited significant increase in reaction time in Eddy's hot plate method in mice at different time intervals. Results were tabulated in Table No. Diclofenac sodium $(30 \mathrm{mg} / \mathrm{kg}$ ) was used as standard and it has significantly increased the reaction time at the end of $1^{\text {st }}$ and $2^{\text {nd }} \mathrm{h}$ which was found to be a time dependent effect. During $30 \mathrm{~min}$ of the study PHME with medium and high dose the reaction time was $3.41,3.50$, seconds. During $60 \mathrm{~min}$ of the study PHME with medium and high dose the reaction time was 4.34 , 4.74, respectively which was time dependent effect. During 120 min of the study PHME with medium and high dose the reaction time was $6.17,7.11$, respectively. During $180 \mathrm{~min}$ of the study PHME with medium and high dose the reaction time was 7.06 , 7.46, 6.17, 7.06 seconds. Diclofenac sodium showed a significant reaction time during $30 \mathrm{~min}$ and $60 \mathrm{~min}$ whereas test groups have shown during 60 and 180min and the results were showed in Table No 2.

Table 2: Analgesic Effect of PHME in Eddy's Hot Plate Method in Mice

\begin{tabular}{|c|c|c|c|c|c|}
\hline \multirow{2}{*}{$\begin{array}{l}\text { Group } \\
\text { s }\end{array}$} & \multirow{2}{*}{ Treatment } & \multicolumn{2}{|c|}{ Hot plate reaction time } & \multirow[b]{2}{*}{$120 \mathrm{~min}$} & \multirow[b]{2}{*}{$180 \mathrm{~min}$} \\
\hline & & $30 \mathrm{~min}$ & $60 \mathrm{~min}$ & & \\
\hline $\begin{array}{l}\text { Con- } \\
\text { trol }\end{array}$ & $\begin{array}{l}\text { Forma- } \\
\operatorname{lin}(1 \% \mathrm{w} / \mathrm{v})\end{array}$ & $\begin{array}{l}2.512 \pm 0.3 \\
182\end{array}$ & $\begin{array}{l}2.386 \pm 0.3 \\
81\end{array}$ & $\begin{array}{l}2.176 \pm 0 . \\
36\end{array}$ & $\begin{array}{l}2.07 \pm 0.3 \\
51\end{array}$ \\
\hline $\begin{array}{l}\text { Stan- } \\
\text { dard }\end{array}$ & $\begin{array}{l}\text { Diclofenac } \\
\text { sodium } \\
(30 \mathrm{mg} / \mathrm{kg})\end{array}$ & $\begin{array}{l}3.545 \pm 0.4 \\
70\end{array}$ & $\begin{array}{l}6.076 \pm 1.1 \\
4 * *\end{array}$ & $\begin{array}{l}9.93 \pm 0.4 \\
5 * *\end{array}$ & $\begin{array}{l}7.93 \pm 0.3 \\
2 * *\end{array}$ \\
\hline $\begin{array}{l}\text { PHM } \\
\text { E }\end{array}$ & $200 \mathrm{mg} / \mathrm{kg}$ & $3.41 \pm 0.18$ & $4.34 \pm 0.21$ & $\begin{array}{l}6.17 \pm 0.2 \\
3^{* *}\end{array}$ & $\begin{array}{l}7.06 \pm 0.1 \\
9 * *\end{array}$ \\
\hline $\begin{array}{l}\text { PHM } \\
\text { E }\end{array}$ & $400 \mathrm{mg} / \mathrm{kg}$ & $3.50 \pm 0.17$ & $\begin{array}{l}4.74 \pm 0.19 \\
*\end{array}$ & $\begin{array}{l}7.11 \pm 0.1 \\
0^{* *}\end{array}$ & $\begin{array}{l}7.46 \pm 0.1 \\
6 * *\end{array}$ \\
\hline
\end{tabular}

\subsection{Carrageenan induced paw oedema in rats}

The PHME in $200 \mathrm{mg} / \mathrm{kg}$ and $400 \mathrm{mg} / \mathrm{kg}$ have exhibited a significant reduction in paw edema volume in Carrageenan induced paw oedema in rats at different time intervals. Results are tabulated in Table No 3. Diclofenac sodium (30 mg/kg) was used as standard reference and it has significantly reduced paw oedema volume which was found to be a time dependent effect. Diclofenac showed maximum response at $4^{\text {th }}$ hour which was found to be $71.43 \%$. At $4^{\text {th }}$ hour PHME showed significant reduction in oedema volume, $400 \mathrm{mg} / \mathrm{kg}$ showed the maximum reduction in oedema volume i.e. $60 \%$.

Table 3: Carrageenan Induced Paw Oedema in Rats

\begin{tabular}{llllll}
\hline \multirow{2}{*}{ Groups } & \multicolumn{5}{c}{ Oedema volume $(\mathrm{ml})$} \\
& $0 \mathrm{hr}$ & $1 \mathrm{hr}$ & $2 \mathrm{hr}$ & $3 \mathrm{hr}$ & $4 \mathrm{hr}$ \\
\hline \multirow{2}{*}{ Control } & $0.17 \pm$ & $0.24 \pm$ & $0.29 \pm$ & $0.32 \pm$ & $0.35 \pm$ \\
Diclofenac & 0.06 & 0.09 & 0.07 & 0.07 & 0.06 \\
sodi- & $0.15 \pm$ & $0.16 \pm$ & $0.12 \pm$ & $0.10 \pm$ & $0.10 \pm$ \\
um(30mg/kg & 0.03 & $0.05^{*}$ & $0.04^{*}$ & $0.04^{*}$ & $0.03^{*}$ \\
) & $(11.77)$ & $(33.33)$ & $(58.63)$ & $(68.75)$ & $(71.43$ \\
& & & & & ) \\
PHME & $0.23 \pm 0.0$ & $0.27 \pm 0$. & $0.24 \pm 0.03$ & $0.21 \pm 0.04$ & $0.22 \pm 0$ \\
200mg & 18 & 039 & $4^{* *}$ & $* *$ & .04 \\
& $(6.66 \%)$ & $(26.9 \%)$ & $(44 \%)$ & $(58.91 \%)$ & $(59.81$ \\
PHME & $0.15 \pm$ & $0.16 \pm$ & $0.17 \pm$ & $0.16 \pm$ & $0.14 \pm$ \\
400mg & 0.04 & $0.05^{*}$ & $0.04^{*}$ & $0.03^{*}$ & $0.06^{*}$ \\
& $(11.77)$ & $(33.33)$ & $(41.39)$ & $(50.00)$ & $(60.00)$ \\
\hline
\end{tabular}

Data presented as mean \pm S.E.M. $\mathrm{n}=6$, $* * * \mathrm{P}<0.001, * * \mathrm{P}<0.01, * \mathrm{P}<$

0.05 , Compared with control group, followed by ANOVA followed by Post hoc test (Dunnett's $\mathrm{s} t$ ' test)

\section{Discussion}

Inflammation is a complex process initiated by several factors ranging from bacterial infection and chemical injury to environmental pollution that result in cell injury or death (O'Byrne KJ et al. 2001). Non-steroidal anti-inflammatory drugs (NSAIDs) are the most commonly used drugs in the world today. Pain and fever are being the most common complaints associated with inflammation. The NSAIDs used in the inflammatory conditions do not cure and remove the underlying cause of the disease but they only modify the inflammatory response to the diseases. Pain and fever are being the most common complaints associated with inflammation. The NSAIDs used in the inflammatory conditions do not cure and remove the underlying cause of the disease but they only modify the inflammatory response to the diseases. Pain and fever are being the most common complaints associated with inflammation. To assess the anti-inflammatory activity, PHME was evaluated by two popular screening models widely used for NSAID namely Carrageenan induced rat paw edema and Formalininduced paw edema. Carrageenan induced rat paw edema shows a biphasic effect. The first phase is due to release of histamine and serotonin $(5-\mathrm{HT})(0-2 \mathrm{~h})$, plateau phase is maintained by kinin like substance $(3 \mathrm{~h})$ and second accelerating phase of swelling is attributed to PG release (4 h). In our study, PHME (200 and 400 $\mathrm{mg} / \mathrm{kg}$, p.o.) significantly $(\mathrm{P}<0.05)$ reduced the edema induced by carrageenan in all three phases.

\section{Conclusion}

On the basis of the study, the data showed that the poly herbal formulation prepared from the dried methanolic extracts of Terminalia chebula, tinospora cordifolia, Phyllanthus emblica, and Portulaca oleracea gave the significant anti-inflammatory activity when compared with standard Diclofenac sodium. As phytochemical tests showed the presence of glycosides, carbohydrates, flavonoids, steroids and resin in the methanolic extracts they might suppress the formation of prostaglandins and bradykinins or antagonize their action and exert its activity. The poly herbal formulation showed which can be useful for the treatment of local inflammation and pain.

\section{References}

[1] Aggarwal, R. P. Kala, Arun Kumar, Neetu Sharma, Savita G (2013). Analgesic Activity of Swertia Chirayita, World Journal of Pharmacy and Pharmaceutical Sciences, 2(5), 3667-3675.

[2] 2. Amrita Kumari, Juhi Rao, Jyoti Kumari, Neha Sharma , Pankaj Jain, Vivek Dave, Swapnil Sharma (2013). Analgesic Activity of Aqueous Extract of Citrullus Lanatus Peels Advances in Pharmacology and Pharmacy 1(3), 135-138.

[3] Ayyasamy S, Kumar A, Nithyamala I, Velpandian V (2013). Evaluation Of Analgesic And Anti Inflammatory Activity Of Siddha Drug Karuvilanchi Ver Chooranam (Root Powder Of Smilax Zeylanica Linn) In Rodent, IOSR Journal of Pharmacy and Biological Sciences, 6 (1), 06-11.

[4] Ezeja M I*, Ezeigbo I I, Madubuike K G (2011). Analgesic activity of the methanolic seed extract of Buchholzia coriacea, Research Journal of Pharmaceutical, Biological and Chemical Sciences, 2(1), 187 .

[5] Hemamalini K,\& Rajini A, Shalini K, Veeresh K, Vijusha M (2013), Analgesic effects of methanolic extracts of Anogeissus latifolia wall on swiss albino mice, Der Pharmacia Sinica, 2013, 4(5), 79-82.

[6] Kalpanadevi V, Mohan V.R and Shanmugasundaram R (2012). Antiinflammatory activity of seed extract of Entada pursaetha DC against carrageenan induced Paw edema, Science Research Reporter 2(1), 6971.

[7] Dalgleish AG. O'Byrne KJ (2001). Chronic immune activation and inflammation as the cause of malignancy. Br. J. Cancer; 85, 473-483. 